\title{
Implementation Based Education (Learning-Gradual) through Traditional Games Mambe Tampun
}

\author{
Feri Wagiono ${ }^{1}$, Syahrial Shaddiq ${ }^{2}$, Sakman $^{3}$, Suprayitno ${ }^{4}$ \\ 1,3,4 Universitas Palangka Raya (UPR), Indonesia \\ 2 Universitas Islam Indonesia (UII) Yogyakarta, Indonesia
}

Corresponding Author: Feri Wagiono, 0 wagionoferi456@gmail.com

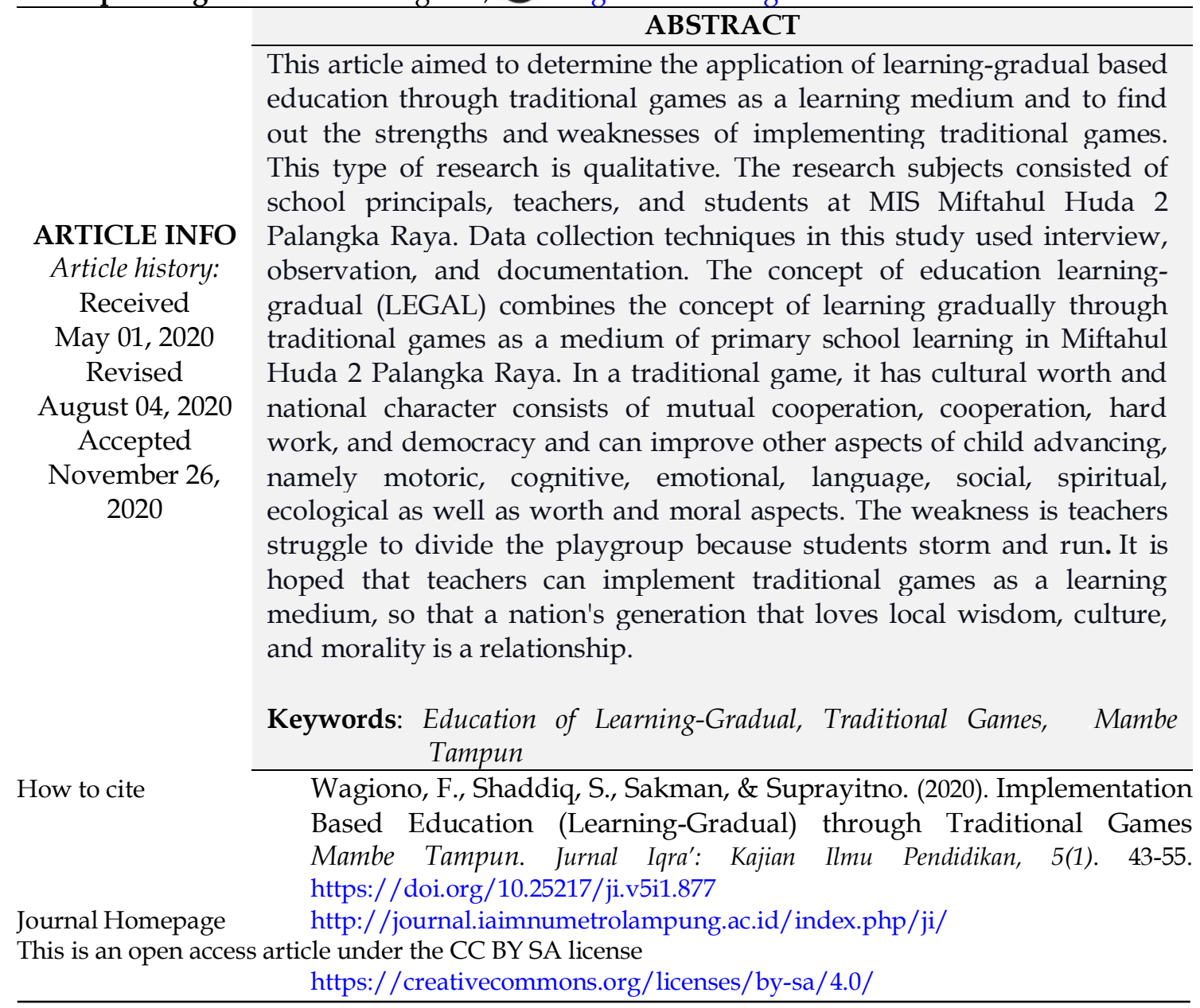

\section{INTRODUCTION}

Today students have grown up in a different generation from previous parents. They believe that something has advanced from the learning method. As we know the Spanish Government funds several research projects (for example APRENDRA). The Spanish Education Act also considers the game as a basic requirement. Because of its motivational aspects, considered to be an ideal resource for use in schools to display the overall content of subject matter andconsidered to be able to enhance learning (Haywood et al., 2009; Hadar, 2009). The Spanish government understands the need to advance varied and fascinating games that provide many learning opportunities and introduce them to schools. This game is contemplated as a methodology for various models of education, which are practiced in formal and non-formal education (Furió et al., 2013). 
In Indonesia the assumption of education as a means or instrument of transfer of the treasury of knowledge and transfer of values. The transfer of knowledge is related to various experiences (Ioannou-Georgiou, 2011; Marttila, 2017). For this reason, systematic and systemic efforts are needed to design learning that conceptually becomes a vehicle for education in the context of character building society. It is ironic that the educational output of this era actually changes the good worth that should be the goal of education, in reality, many are left behind. This can be seen in various examples of the character of the young generation today such as not caring (respect) towards others, not loving others, do not have an attitude of empathy for others, and are more likely to be selfish and individualistic. Many cases of student brawl, violence in schools committed by seniors, violence perpetrated by children against parents, and lack of concern for problems in their environment (Lestari, 2016; Karliani, 2014) Based on the current phenomenon, the younger generation should be introduced to educational games.

Traditional games are now becoming obsolete and not famous. Traditional games are the hallmark and distinctive of the Indonesian nation and have great potential to be used in learning in elementary schools (Černá \& Svobodová, 2015; Pole, N., \& Ablon, 2010). Traditional games born thousands of years ago are the result of the process of human culture that is still thick with the values of local wisdom. Although it is very old it turns out that traditional games have a role educational very effective for the learning process of individuals, especially children. Naturally, traditional games can stimulate various aspects of child development, namely: motor, cognitive, emotion, language, social, spiritual, ecological, and moral worth (Misbach, 2006; Rachael, 2000).

In the digital era that is increasingly advancing, it is when humans not only compete with humans but of course start to compete with technology, at that time also human resources have decreased (Flogie et al., 2020; Naisbitt, 2002). Humans as if spoiled by the increasingly sophisticated technology (Petrova, A., \& Podzygun, 2018). With the advancement of increasingly sophisticated technology. Traditional games are now becoming obsolete and displaced by the presence of modern such as video games and virtual games other, online games that are so sophisticated that they can attract a wide audience to the game and encourage prolonged involvement (Cooper S., et al 2010; Chen,. et al 2010). Sophistication and fascinating facilities in modern games can hypnotize children. With this sophistication, but on the other hand, the game can dwarf the child's potential to advance. Unwittingly, this can lead children to isolate themselves with their environment (Aarssen, L. W., \& Crimi, 2018).

Previous research relevant to this research was conducted by (Lin \& Cheng, 2010) entitled "Effects of the Gradual Release of Responsibility Model on Language Learning". This research was conducted by surveying eighty students who learned languages as their mother tongue. The results revealed that students made progress in writing summaries and had a positive attitude towards teaching. Lin \& Cheng's research has similarities with this research that focuses on gradual learning. And the difference is Lin \& Cheng's research that examines the gradual learning process in English while the research examines the gradual learning system through the traditional game of Mambe Tampun on Citizenship Education (PKn). Furthermore, research conducted by (Iswinarti, 2010) entitled "Therapeutic Values of Traditional Engklek Games For Elementary School Age Children". The results showed that therapeutic worth contained in the traditional Engklek game consists of: (1) Early detection worth, (2) worth for good physical development, (3) worth for good mental health. And the difference in this research is that Iswinarti researched the value 
contained in the traditional game of crank. While the research is focused on the traditional game Mambe Tampun on the gradual Learning of citizenship education (PKn). According to (Furió et al., 2013) conducting a study entitled "Evaluation of Learning Outcomes Using an Educational iPhone Games vs. Traditional Games "the purpose of this study is to compare learning evaluations using traditional games with traditional games. Furio'S Research has in common with this study, which focuses on learning through games for the transmission of knowledge as part of multiculturalism, solidarity, and tolerance. And the difference is Furio's research that examines the learning process using educational games iPhone vs. traditional games While this research examines gradual learning using traditional games.

This research is essential to communicate and help the Government to solve the problems of the younger generation experiencing moral decadence that requires the support of character education integration in learning. Traditional games result from Indonesian culture which is still strong with local wisdom values and has an educational role that is very effective for the individual learning process, especially children. Describing How to implement learning-gradual based education through traditional games as learning in elementary school or to know the advantages and disadvantages of the application of traditional games Mambe Tampun which has the value of culture and character of the nation consists of mutual cooperation, hard work and democratic.

\section{METHODS}

This research is qualitative. This is based on the type of research data in the form of qualitative data. This research has research subjects namely the principal, teachers, and students of MIS Miftahul Huda-2 Palangka Raya. The research subject is the main source of research data, which has data on the variables studied (Lion, 2013; Moser \& Korstjens, 2018). Data research is information about the application and advantages of gradual learning-based education through traditional Mambe Tampun as a learning medium in MIS Miftahul Huda-2 Palangka Raya. Sources of research data are grouped into two types, informants and documentation. The informants consisted of school principals, teachers who taught students, and MIS Miftahul Huda-2 Palangka Raya students who were playing. Documentation of the application of learning-gradual education through traditional games Mambe Tampun as learning media in MIS Miftahul Huda-2 Palangka Raya.

Data collection In this study uses interviews, observations, and documentation. The interviewees are principals, teachers who teach students, and students of MTS Miftahul Huda-2 Palangka Raya who play games. Interview techniques are used to explore data on the preparation of teaching materials, media, methods, and application of ethics and moral in the implementation of learning-gradual based education through traditional games Mambe Tampun, strengths and weaknesses learning-based education gradual through traditional games Mambe Tampun as a Learning media citizenship education (PKn) in MIS Miftahul Huda-2 Palangka Raya. The Interview was in-depth to the principal, a class IV Guardian teacher, and 12 class IV students MIS Miftahul Huda-2 city Palangka Raya. The observation was done on the form of readiness of teachers in the application of traditional games Mambe Tampun as a learning medium of PKn-grade IV in MIS Miftahul Huda-2 Palangka Raya and started by distributing brochures and pamphlets to class IV students at MIS Miftahul Huda-2 Palangka Raya. Documentation in the form of research reports on the daily journal of Learning students Traditional game implementation and the role of teachers in the 
implementation of traditional games Mambe Tampun as a learning medium of PKn-class IV in MIS Miftahul Huda-2 Palangka Raya. The validity of the data in this study uses triangulation. According to (Moleong, 2007; Tuma, J. M., \& Pratt, 2006) distinguish triangulation, such as source triangulation, investigators and triangulation techniques in this study are triangulation of sources and techniques (Simonson, 2016). Data analysis techniques are carried out in several stages; namely data reduction, data collection, display data, and conclusion drawing or verification.

\section{RESULT AND DISCUSSION}

Education is to increase personal potential, which is spiritual (thought, intention, taste, creativity, and conscience). Education is also the institution responsible for setting ideals (goals), content, systems, and educational organizations. This institution consists of families, schools, and communities (Ihsan, 2015; Farkas, 2015). According to Dewantara (2004), education is a demand in the lives of children (Dewantara 2004; House at al., 2009). The point is that education leads all activities to build a civilized culture of human civilization so that students as humans and members of the community can achieve high safety of the glory of life (Cao et al., 2019). Thus concluded that education as a process of advancing individual aims to form attitudes and behaviors that are useful for the community (Katz, 2012; Mark, 2018). The process can be influenced by the environment which can later reach social skills and advance their personality.

\section{Based on education Learning-Gradual (LEGAL)}

Learning-Gradual is a combination of two words Learning and Gradual. Learning means learning, based on the Great Dictionary of Bahasa Indonesia (KBBI) (Poerwadarminta, 2003) The meaning of Gradual is the stage, gradually in learning it is effective to improve student learning outcomes (Lin \& Cheng, 2010; Pithers \& Soden, 2000). According to the authors, Learning-Gradual (LEGAL) means the stages that occur in learning. Thus Learning-Gradual can adapt to the whole science that is in the community (Amalberti, 2001; Chen et al., 2010; Ji, Y., 2019) . It can be concluded that Learning-Gradual-based education is the process of advancing an individual to shape attitudes and behaviors that are useful to the community, influenced by stages in learning that can later be achieved with a particular purpose.

\section{Traditional Games as a Form of National Relationship}

Education has been known in the world with a variety of terms in America known as moral education, in England with value education and Indonesia by the name of moral education and moral worth of Pancasila (Ajat, S., 2011; Slamet, 2006). Education that produces character has long been echoed by the father of Indonesian education, Ki Hadjar Dewantara. Education without character will only produce humans without morals (Marttila, 2017; Farkas, 2015). Family and community have an important role in the advance of children's character. Traditional games have some worth of character education in them, although at present traditional games have less relevant perceptions with the demands of the times. This character education is very important to instill from an early age as a form of preservation of national culture and character building by the identity of the Indonesian people (Slamet, 2006).

According to Iswinarti (2010) said that the role of play in children has an impact on several areas of children's lives consists (1) Play has an important role in learning in this case, play can complement children's school activities, which can give children opportunities understand, absorb, and give meaning to what they learn informal education settings. Specifically playing becomes important helping children to obtain 
not specific information but a general mindset in problem-solving; (2) Playing supports physical development and good mental health. Play facilitates children in physical activities, including activities for sports, which allows increased coordination and balance of the body, as well as advancing skills in children's growth (Pole, N., \& Ablon, 2010). The contribution to mental health is to help children to build and advance resilience (resistance) to stresses in life; (3) Playing allows testing the child is facing challenges and dangers (Iswinarti, 2010; Pole, N., \& Ablon, 2010).

Based on the description above, it can be understood that playing should have a positive impact on children. If explored more deeply it turns out the meaning behind the values of traditional games that contain moral worth messages with the content of local wisdom sublime, it is very unfortunate if the current generation does not recognize and appreciate the worth raised from the diversity of ethnic groups in Indonesia. Traditional games are very good at influencing their social interactions (Furió., 2013).

Central Kalimantan's traditional games consist of: Slashing, Choking, Bagasing, Stilts Racing, Shooting Tutus, Sebumbun, Sakei Uei, and Mambe Tampun (Direktorat Jenderal Kebudayaan Direktorat Sejarah dan Nilai Tradisional Proyek Pengkajian dan Pembinaan Nilai-Nilai Budaya, 1995). Traditional games will have a significantly better impact on the development of children's potential. The results of his research stated that traditional games can advance social skills that are job together, adjusting, interacting, controlling themselves, empathy, obeying, and respecting others. It also understands, permeates, gives meaning and mental health, and helps children to advance resilience or endurance.

Learning media as a component is vital in the learning process. This is one of the determinants of the success or failure of a grade or content delivered to students. The media is one component of communication that is as a messenger from the communicator to the communicant (Farkas, 2015). The media functions as a carrier of information from the source (teacher) to the recipient (students) so the learning process will run optimally if the media performs its function properly (Hadar, 2009). So, media has a very important role in learning.

The process of teaching and learning is necessary to use the concept of learning that is good, effective, and enjoyable to achieve learning objectives. The concept of learning based on learning-gradual is to create conditions for gradual teaching and learning in the form of effective and fun interactions between teachers and students based on the stages that occur in learning. Also, the learning objectives are quite broad in scope not only in the classroom but can also be done outside the classroom or schoolyard. Learning is done through games to make students understanding faster because of direct observation or practice of the theory obtained (Farkas, 2015; Garris, R., Ahlers, R., \& Driskell, J. E., 2002). It's different compared to learning that only reads theory, not infrequently the complaints of students that we often hear. According to the interview, the author with Mrs. Nasiroh as the principal said: "Learning only read the theory, often we hear students complaints sometimes bored" (Nasiroh, interview 6 November 2019).

Based on the above opinion shows that learning only read the theory, it is not uncommon to hear students ' complaints so it is important to learn to do direct observation or the practice of theories acquired. The concept of learning based on Gradual can be done anywhere both in the classroom and on the school environment. Components of Learning-Gradual consists of (1) Teachers and students, (2) Materials, (3) Teaching Materials, and (5) Learning Media. The social interaction model is a 
learning model that emphasizes concepts Gradual.

Based on the Gestalt learning theory (field theory) in (Abdurrahman, 2015) this model says a harmonious relationship between individuals and the community of school residents (learning to live together). The application of this theory consists of (1) Experience (insight/ insight), the ability of students to recognize the interrelation of elements in objects in the learning process. Teachers should advance student's ability to solve problems with insight; (2) Meaningful learning, the meaningfulness of the elements involved in an object will support the learning process. Content that students learn should have clear meanings for themselves and future lives; (3) Aimed behavior, directed behavior towards a goal. Learning on students will succeed because they know the objectives to be achieved (Ioannou-Georgiou, 2011) and (4) Principle of life space, student behavior related to the environment. The material presented has to do with the situation wherever students are.

Classification of learning approaches based on subjects and objects. The process learning-gradual uses a subject learning approach namely the teacher and the object means students. Theory constructivism is a view used in the learning process Gradual (Ji, et al., 2010). According to this understanding, learning is the result of students' construction as a result of interaction with the learning environment. The teacher is more like a facilitator in building children's knowledge. In student-centered learning, it places students as individuals who have the seeds of knowledge in themselves who need various activities to advance them into a meaningful understanding of things. Students have more responsibility to monitor their learning progress (Nunung, interview 6 November 2019).

Based learning by the author is first, the teacher before learning to look for references or guide books. Second, the teacher shows the game guide rules brochure or pamphlet and explains the game concept and material explanation. Third, students play traditional games directed by the teacher and added learning material to each game in the classroom and on the school grounds. Then finally the students are given questions to evaluate learning and conclude learning.

\section{Steps to Implement Based Education Learning-Gradual through Traditional Games}

Steps to implement based education Gradual Learning through traditional games as learning media for PKn Class IV MIS Miftahul Huda-2 Palangka Raya include: (1) Preparation of teaching materials, teaching materials can be adapted to the material to be taught in the game; (2) Learning Media, a means that serves to channel knowledge from the instructor to students. The media used are blackboards, printed books, notebooks, pencils or ballpoint pens, markers, erasers, and traditional playing instruments; (3) Learning methods, using classroom systems indoor and outdoor, providing educational games like traditional games. The classroom system indoor uses classrooms in the School. While classroom outdoor doing in the school environment, in environments outside of school or the socio-cultural environment; (4) Application of ethical and moral education. In addition to the knowledge taught, the application of ethics and morals is needed to minimize the future social storage; and (5) Evaluation in Learning-Gradual Learning places more emphasis on formative evaluation that is using a question and answer test, students will be trained to motivated and not be motivated by rote learning (Nunung, interview 6 November 2019).

\section{Mambe Tampun as Learning Media in PKn Subjects Class IV MIS Miftahul Huda-2} Elementary School Palangkaraya

Mambe Tampun is a traditional game derived from the Dayak Maanyan Language of South Barito, Central Kalimantan Province consisting of two words 
namely Mambe and Tampun. Mambe means ghosts while Tampun means blind, so Mambe means a ghost is blind. The game can be done by men and women. Aged 7 to 12 years of elementary school age. This game is usually done by participants if more than two people, between 3 to 12 people. The application of the traditional game Mambe Tampun as learning media Citizenship Education (PKn) Class IV MIS Miftahul Huda-2 Palangka Raya.

\section{Techniques of Application of Traditional Games Mambe Tampun}

Techniques of Application of Traditional Games Mambe Tampun as learning media Citizenship Education (PKn), among others, (1) Game name is Mambe Tampun; (2) Participants: Around 3-12 people, some who act as Mambe Tampun, others who act as enemies; (3) Equipment used: Handkerchief for closing eyes; and (4) How to play: (a) Players make a circle with a diameter of 2 to 2.5, meters as a playing field, then all players and Mambe will enter the circle, and (b) The rule is that players who run are limited to a circle. It is in this circle that Mambe Tampun, who is blindfolded, looks for opponents who run around, Mambe Tampun who manages to catch his opponent must say what his name is.

\section{The Moral Worth}

The moral worth contained is (1) Democracy: Realized in the election that will be Mambe Tampun with a suit, (2) Hard Work: Perseverance of participants who act as Mambe Tampun is developed, and (3) Mutual cooperation: Cooperation the player to trick the Mambe Tampun so that his friend is not caught. Players are Mambe Tampun aware and aware of the worth applied through the practice of simulating learning methods that are centered on students and other changes in educational practice (Giannakos, 2013), using classroom systems indoor and outdoor, providing educational games is very students need to have a large impact on learning procedures (Giannakos, 2013; Garris et al., 2002) such as traditional games. Likewise, educational games involve students in the repeated assessment of feedback behavior (Garris et al., 2002). The game with the potential to advance skills in decision making, design, strategy, cooperation, and problem-solving (McFarlane et al., 2002).

Then the teacher explains the subject matter of PKn related to Democracy, Mutual Assistance, and Cooperation and then gives Evaluation in Learning to put more emphasis on formative evaluation that is using a question and answer test, students will be trained to think and not be motivated by rote learning. Students are happy and not bored with learning activities because of educational games (Azam, interview 7 November 2019). In the traditional game, it has cultural worth and national characters consist of mutual cooperation, cooperation, hard work, and democracy It is also a benchmark forming the character of a young generation who is ready to mentally in the face of the era of globalization or the era of gadgets that are dynamic in the modern era (Nunung, interview 6 November 2019).

Contributing factors are factors or causes of the occurrence of something supportive or justified, while the inhibitory factor is the cause of the failure to be desired (Flogie et al., 2020) consists of: The strengths of learning approaches are student-centered in this learning consisting of 1) inexpensive cost without the need for advanced tools, 2) can be done in the classroom or the schoolyard, 3) high learning interests in students, 4) students actively advance knowledge and skills learned, 5) Knowing the implications of the theory that has been taught, 6) Achieving student competencies and not just material, and 7) students are happy and not bored in learning activities because through educational games (Riski, interview 7 November 2019). The weakness of this learning approach is that teachers are still struggling to 
divide the playgroup because students are noisy and running around here.

The findings in this study are the stages of learning through traditional games as a learning medium of PKn-class IV MIS Miftahul Huda-2 Palangka Raya consisting of (1) Preparation of teaching materials, it can be adjusted to the material to be taught in the game; (2) learning Media, Sarana that serves to distribute knowledge from teachers to students. The Media used are whiteboards, printed books, notebooks, pencils or ballpoints, markers, erasers, and traditional game tools; (3) learning Methods, using indoor and outdoor class systems, educational games such as traditional games; (4) the application of ethical and moral education. In addition to the knowledge taught, the ethical and moral application is indispensable to minimize the social storage that will occur later; and (5) evaluation in learning Learning-Gradual More emphasis on formative evaluation is using a test of questions and answers, learners will be trained to think and not be racing on memorization. The concept of the first lesson, the teacher before learning seeks reference or Handbook. Secondly, the teacher while showing brochures or Pamphlet rules of the game hints as well as describing game concepts and material explanations. Thirdly, the student plays traditional games with pleasure, teachers directing and add learning Materials of PKndemocracy, and team and cooperation on each game in the classroom as well as in the schoolyard. Then the last students were given questions for the evaluation of learning and concluding learning. The Moral value contained in the traditional game of Mambe Tampun consists of (1) Democracy: manifested in the election that will become "Mambe Tampun" with Suit, (2) hard work: The persistence of participants acting as "Mambe Tampun" was developed, and (3) and team: the cooperation of players to trick the Traditional game of Mambe Tampun as the local wisdom of the Indonesian nation has the value of culture and nation characters such as and team, cooperation, hard work and democratic. The students are happy and not bored in learning activities because through educational games.

This finding was in line with the findings of several previous studies for instance (Lin \& Cheng, 2010), conducted by surveying eighty students who learned languages as their mother tongue. During the learning process, they go through several different stages: model instruction, guided instruction, collaboration with peers, and independent learning. The results revealed that students made progress in writing summaries and had a positive attitude towards teaching. It is fascinating to note that more students prefer practicing with peers for longer periods than with teachers. It implies that students feel more beneficial to a job with peers and have more control over their job than just contributing to the job of the teacher on the board. Lin \& Cheng's research has similarities with this research that focuses on gradual learning. And the difference is Lin \& Cheng's research that examines the gradual learning process in English while the research examines the gradual learning system through the traditional game of Mambe Tampun on Citizenship Education (PKn). Furthermore, research conducted by (Iswinarti, 2010) showed that therapeutic worth contained in the traditional Engklek game consists of: (1) Early detection worth, (2) worth for good physical development, (3) worth for good mental health, (4) worth of problem-solving, and (5) Social worth. The similarity between this research and the Iswinarti research highlights the values contained in traditional games for children. And the difference in this research is that Iswinarti researched the value contained in the traditional game of crank. Traditional game was one of the cultures inherited of hereditary society which has great value to society (Suhono \& Sari, 2017). While the research is focused on the 
traditional game Mambe Tampun on the gradual Learning of citizenship education (PKn).

According to (Furió D., González-Gancedo, S., Juan, MC, Seguí, I., \& Rando, N., 2013) conducting a study that compare learning evaluations using traditional games with traditional games. Although there are slight differences researchers believe that children achieve the same increase in knowledge using both iPhone games and traditional games. It can facilitate the versatility of the learning process and can be a useful tool in helping teachers learn with the training needs of students. Furio'S Research has in common with this study, which focuses on learning through games for the transmission of knowledge as part of multiculturalism, solidarity, and tolerance. And the difference is Furio's research that examines the learning process using educational games iPhone vs. traditional games While this research examines gradual learning using traditional games of Mambe Tampun as the local wisdom of the Indonesian nation has the value of culture and nation characters such as and team, cooperation, hard work and democratic. And then in line with the findings of Ajat's research (Ajat, S., 2011) in the era of globalization, educational institutions not only create competent and quality humans according to technological advances but also education must make human beings with noble character. Ajat's research has similarities with this research that focuses on character education is not only aimed at understanding but the stage of the application or implementation of ethical values and character. Deviation of Indonesian human morality needs to be anticipated with character education and it needs to be taught since childhood because humans are only smart without morals which will disturb society. And the differences in Ajat's research on character education while this study simultaneously uses the traditional game of mambe tampun. According to (Misbach, 2006) Misbach's research has similarities with this research that focuses on traditional games are also the culture of the Indonesian nation that fosters positive characters in children such as moral messages, shared values, responsibility, generosity, and obeying regulations. Traditional games do not mean leaving gadget games, but both work synergistically to create Indonesian people with character but also not behind the development of the world of technology and information. And what distinguishes this research is that Misbach examines the role of educational traditional games in contributing to the formation of national character and identity. While the research is focused on the traditional game mambe tampun Citizenship Education (PKn). According to (Slamet, 2006) Slamet's research has similarities with this research that focuses on the importance of implementing an education system that can answer the challenges of the times (knowledge and skills) as well as strengthen the nation's character (attitude) because human development with the moral character of Pancasila is a long-term investment that is the main key to the progress of a nation and its sovereignty. In utilizing the demographic bonus properly, qualified leadership is needed along with the visionary breakthroughs needed by the government to improve the quality of Indonesian people as a whole. Therefore, Indonesia will be able to compete fairly with other countries. And what distinguishes this research is Slamet's research on the philosophy and ideology of Pancasila. While the research is focused on the traditional game mambe tampun in Citizenship Education (PKn).And then in line with the findings of (Ihsan, 2015) Ihsan's research has similarities with this research that focuses on education is a means that can be used as the development of social capital which means human resources who have honesty, trust, willingness, and ability to cooperate, coordinate and have the habit of contributing to the development of community character. Along with the development 
of the era of education, it has opened up people's mindset for a better life and the Indonesian nation. And the difference this research is that the research is only related to the basis and essence of education. While the research is focused on traditional games and learning. According to (Černá \& Svobodová, 2015) real evidence that currently, children are more enthusiastic about technology-based digital games. Digital games such as video games and online games are mostly played statically by children playing in a passive state. They sit and stay still, only their fingers work. Therefore, children do not care about their environment which affects children's social interactions, as a result, children become shy, lonely, and individualistic. And it has a difference with Černá \& Svobodová's research that digital games such as video games and online games are played more statically regardless of the environment that affects children's social interactions, whereas this study is a traditional game for the development of the quality of children's moral character referring to actions and behavior. This research has implications for the form of reference to the stage of learning communication to the students. The moral education in Indonesia in the future will have many challenges, so it takes a method of learning to the students integrated with the value of the nation's character in traditional games.

\section{CONCLUSIONS}

The concept of based education Learning-Gradual combines the concept of learning gradually and environmentally based on traditional games. The concept of this based education is not only in the classroom but also in the scope of society and the natural environment. The traditional game of Mambe Tampun from the Dayak language of Maanyan Barito Selatan, Central Kalimantan Province can be used as a PKn learning media with democratic values, mutual cooperation, and hard work. With traditional games, it does not necessarily mean leaving digital games, and vice versa. So both must synergize to realize the character of the younger generation that is in line with national identity but also not left behind to find out the various positive benefits of technological and information development. Students are happy and not bored with learning activities because of educational games. In the traditional game, it has cultural values and national characters such as mutual cooperation, cooperation, hard work, and democracy and can improve the social, value, and moral aspects. It is hoped that teachers can implement traditional games as a medium of learning in schools by involving school members, parents, and the community, to create a generation of people who love local wisdom, culture, and morality.

\section{ACKNOWLEDGEMENTS}

The author highly appreciates Hj. Nasiroh as MIS School Principal Miftahul Huda-2 Palangka Raya to give permission to conduct research. Then, thanks for the guidance that has motivated the author to immediately complete this research.

\section{AUTHOR CONTRIBUTION STATEMENTS}

The author had participated in the research and approved the final version of the manuscript.

\section{REFERENCES}

Aarssen, L. W., \& Crimi, L. (2018). Playing the objectification game: How women's selfesteem impacts the existential consequences of objectification. In Dissertation Abstracts International: Section B: The Sciences and Engineering. ISBN: 0419-4217 
Google Scholar

Abdurrahman. (2015). Teori Belajar Aliran Psikologi Gestalt Serta Implikasinya Dalam Proses Belajar dan Pembelajaran. 1 No.2,14-21. Google Scholar

Ajat, S. (2011). Mengapa Pendidikan Karakter? Pendidikan Karakter, 1-12. https:// doi.org/https:// doi.org/10.21831/jpk.v1i1.1316

Amalberti, R. (2001). The paradoxes of almost totally safe transportation systems. Safety Science. https:/ / doi.org/10.1016/S0925-7535(00)00045-X

Cao, Y., Postareff, L., Lindblom-Ylänne, S., \& Toom, A. (2019). Teacher educators' approaches to teaching and connections with their perceptions of the closeness of their research and teaching. Teaching and Teacher Education. https://doi.org/10.1016/j.tate.2019.06.013

Černá, M., \& Svobodová, L. (2015). Development of financial and language competences via on-line games and tests. Proceedings of the European Conference on E-Learning, ECEL. Google Scholar

Chen, J., Man, H., Yen, N. Y., Jin, Q., \& Shih, T. K. (2010). Dynamic navigation for personalized learning activities based on gradual adaption recommendation model. Lecture Notes in Computer Science (Including Subseries Lecture Notes in Artificial Intelligence and Lecture Notes in Bioinformatics). https://doi.org/10.1007/978-3-642-17407-0_4

Cooper, S., Khatib, F., Treuille, A., Barbero, J., Lee, J., Beenen, M., Leaver-Fay, A., Baker, D., Popović, Z., \& Players, F. (2010). Predicting protein structures with a multiplayer online game. Nature. https:// doi.org/10.1038/nature09304

Dewantara I, . (2004). Pendidikan dan Pengajaran menurut Ki Hajar Dewantara. Jogjakarta: Majelis Leluhur Taman Siswa.

Direktorat Jenderal Kebudayaan Direktorat Sejarah dan Nilai Tradisional Proyek Pengkajian dan Pembinaan Nilai-Nilai Budaya. (1995). Permainan Rakyat Daerah Kalimantan Tengah. Kalimantan Tengah. Departemen Pendidikan dan Kebudayaan.

Farkas, W. A. (2015). Designing, implementing, and evaluating a middle school English language arts program: A mixed methods approach. (Doctoral dissertation, Oakland University).Google Scholar

Flogie, A., Aberšek, B., Aberšek, M. K., Lanyi, C. S., \& Pesek, I. (2020). Development and Evaluation of Intelligent Serious Games for Children With Learning Difficulties. 8(2), e13190. JMIR Serious Games Google Scholar

Furió, D., González-Gancedo, S., Juan, M. C., Seguí, I., \& Rando, N. (2013). Evaluation of learning outcomes using an educational iPhone game vs. traditional game. Computers and Education. https:/ / doi.org/10.1016/j.compedu.2012.12.001

Garris, R., Ahlers, R., \& Driskell, J. E. (2002). Games, motivation, and learning: A research and practice model. Simulation and Gaming. https://doi.org/10.1177/1046878102238607

Giannakos, M. N. (2013). Enjoy and learn with educational games: Examining factors affecting learning performance. Computers and Education. https://doi.org/10.1016/j.compedu.2013.06.005

Hadar, L. (2009). Ideal versus school learning: Analyzing Israeli secondary school students' conceptions of learning. International Journal of Educational Research. https://doi.org/10.1016/j.ijer.2009.01.002

Haywood, N., Walker, S., O'Toole, G., Hewitson, C., Pugh, E., \& Sundaram, P. (2009). Engaging all young people in meaningful learning after 16: A review. Equality and Human Right Commission. Manchester, UK Google Scholar

House, F., Road, C., \& Ls, L. (2009). Innovations in Education and Teaching 
International Rethinking $\mathrm{PhD}$ learning incorporating communities of practice Rethinking $\mathrm{PhD}$ learning incorporating communities of practice. Innovations in Education and Teaching International. https:// doi.org/10.1080/14703290903069019

Ihsan, F. (2015). Dasar-dasar Kependidikan. PT Asdi Mahasatya.

Ioannou-Georgiou, S. (2011). Transition into CLIL: Guidelines for the beginning stages of CLIL. Guidelines for CLIL implementation in Primary and Pre-primary Education. 3438. Google Scholar

Iswinarti. (2010). Nilai-Nilai Terapeutik Permainan Tradisional Engklek Untuk Anak Usia Sekolah Dasar. Naskah Publikasi Penelitian Dasar Keilmuan, 1-16. Google Scholar

Ji, Y., Lu, Y., Yang, F., Shen, W., Tang, T. T. T., Feng, L., Duan, S., \& Lu, B. (2010). Acute and gradual increases in BDNF concentration elicit distinct signaling and functions in neurons. Nature Neuroscience. https:// doi.org/10.1038/nn.2505

Karliani, E. (2014). Membangun Civic Engagement Melalui Model Service Learning Untuk Memperkuat Karakter Warga Negara. Jurnal Pendidikan Pancasila Dan Kewarganegaraan, 27(2), 71-78. Google Scholar

Katz, J. (2012). Teaching to diversity: The three-block model of universal design for learning. Portage \& Main Press. Google Scholar

Lestari, P. dan S. (2016). Membangun Karakter Siswa Melalui Kegiatan Intrakurikuler, Ekstrakurikuler dan Hidden Curriculum di SD Budi Mulia Dua Pandeansari Yogyakarta. Jurnal Penelitian, Volume 10. Google Scholar

Lin, N. C., \& Cheng, H. F. (2010). Effects of gradual release of responsibility model on language learning. Procedia - Social and Behavioral Sciences. https:// doi.org/10.1016/j.sbspro.2010.03.1000

Lion, E. dan H. Y. B. (2013). Metodologi Penelitian Kualitatif. Jenggala Pustaka Utama.

Mark, S. L. (2018). A bit of both science and economics: a non-traditional STEM identity narrative. Cultural Studies of Science Education. 13(4), 983-1003. Google Scholar

Marttila, K. L. (2017). Determining the Effectiveness of the Saxon Math Program and the Ready Common Core Program for Students with Disabilities. In ProQuest LLC. Google Scholar

McFarlane, A., Sparrowhawk, A., \& Heald, Y. (2002). Report on the educational use of games. TEEM (teachers evaluating educational multimedia). Google Scholar

Misbach, I. (2006). Peran Permainan Tradisional Yang Bermuatan Edukatif Dalam Menyumbang Pembentukan Karakter Dan Identitas Bangsa. Tesis UPI Bandung: Tidak Diterbitkan.

Moleong, L. . (2007). Metode Penelitian Kualitatif. Remaja Rosda Karya.

Moser, A., \& Korstjens, I. (2018). Series: Practical guidance to qualitative research. Part 3: Sampling, data collection and analysis. European Journal of General Practice. https:/ / doi.org/10.1080/13814788.2017.1375091

Naisbitt, J. E. A. (2002). High Tech High Touch. Pustaka Mizan.

Petrova, A., \& Podzygun, O. (2018). Implementation of information and communication technologies in teaching a foreign language for professional communication. Professional competency of modern specialist: means of formation, development and improvement. 163-176. Google Scholar

Pithers, R. T., \& Soden, R. (2000). Critical thinking in education: A review. In Educational Research. https:// doi.org/10.1080/001318800440579

Poerwadarminta, W. J. . (2003). Kamus Besar Bahasa Indonesia. PN Balai Pustaka.

Pole, N., \& Ablon, J. (2010). Teaching students to become self-reflective practitioners. Therapeutic Recreation Journal. Google Scholar 
Rachael, V. S. Y. (2000). Digital game-based learning. C++/Rachael Voo Sze Ying (Doctoral dissertation, University of Malaya). Google Scholar

Simonson, M. (2016). Annual Proceedings of Selected Research and Development Papers Presented at the Annual Convention of the Association for Educational Communications and Technology (39th, Las Vegas, Nevada, 2016). Volume 1. The Annual Convention of the Association for Educational Communications and Technology (39th, Las Vegas, Nevada, 2016).Google Scholar

Slamet, S. (2006). Filsafat dan Idiologi Pancasila. Andi Offset.

Suhono, S., \& Sari, Y. A. (2017). Retrofitting Javanese traditional games as Indonesia culture identity: Providing English vocabulary. Jurnal Iqra': Kajian Ilmu Pendidikan, 2(1), 213-226. https:// doi.org/10.25217/ji.v2i1.123

Tuma, J. M., \& Pratt, J. M. (2006). Action research and reflective practice: towards a holistic view Action Research and Reflective Practice: towards a holistic view. Educational Action Research. Google Scholar

\section{Copyright Holder :}

(c) Wagiono, F., Shaddiq, S., Sakman, \& Suprayitno. (2020)

First Publication Right :

(C) Jurnal Iqra' : Kajian Ilmu Pendidikan

This article is under:

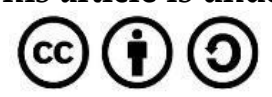

